\title{
SIMULATION OF THE LENGTH OF SUGARCANE (Saccharum spp.) CROP ROWS IN THE OPERATIONAL MANAGEMENT OF SPRAYING
}

\author{
SIMULAÇÃO DO COMPRIMENTO DAS FILEIRAS DE CULTIVO DE CANA-DE- \\ AÇÚCAR (Saccharum spp.) NO GERENCIAMENTO OPERACIONAL DA \\ PULVERIZAÇÃO
}

\begin{abstract}
Neisvaldo Barbosa dos SANTOS ${ }^{1}$
1. Professor Assistente B II de Mecânica e Mecanização Agrícola, do Campus Professora Cinobelina Elvas, da Universidade Federal do Piauí - UFPI, Brasil. Doutorando em Engenharia Agrícola (Engenharia de Sistemas Agrícolas) pela Universidade Federal do Ceará - UFC, Brasil. neisvaldo@gmail.com
\end{abstract}

\begin{abstract}
Brazil is the world's largest producer of sugarcane destined to mills and has an average productivity higher than that of other producing countries of this raw material. The application of agricultural control products in sugarcane fields of agroindustries is carried out in extensive cultivation areas with hydraulic self-propelled, trailed, and aerial sprayers. For this, the systematization of cultivation areas, making longer the length of crop rows in the cultivation plots, is necessary to reduce the bedside maneuvers of machinery. This study aimed to assess the impact caused by the length of crop rows on the operational cost of the hydraulic sprayer used for sugarcane management practices. Due to the difficulty in performing this study and meeting the aim under field conditions, a computational model called TratoCana was developed in a spreadsheet and programming language. The model was verified for possible routine errors, validated, and used in the factor analysis and generation of scenarios. The results showed that the length of crop rows positively affects the operational and economic performance of the equipment.
\end{abstract}

KEYWORDS: Agricultural mechanization. Hydraulic sprayers. Planning and management. Bedside maneuver. Computational model. Cost.

\section{INTRODUCTION}

In Brazil, sugarcane planted area for the 2017/2018 season is estimated at 8.74 million hectares, with a total production estimated at 635.60 million tons (CONAB, 2017).

The mechanized spraying system of sugarcane mills has its operational and economic performance influenced by the systematization of the planted area. According to Santos and Gadanha Júnior (2016), the plots should be adjusted in a rectangular geometric shape or winding strip in order to increase the length of crop rows and reduce bedside maneuvers of the machinery. Because of this, the length of crop rows is directly related to the operational and economic performance of the machinery.

For this, the management of agricultural machinery considers operational and economic performance. The operational performance consists of the variables operating speed, field efficiency, operational field capacity, worked hours, machinehours, and number of equipment required. On the other hand, economic performance is formed by annual, hourly, and variable fixed costs (BALASTREIRE, 1990; HUNT, 1995; MIALHE,
1974).

According to Santos et al. (2015b) apud Williams (2008), in the management for selecting agricultural machines, computational modeling has been adopted because it is a tool that simplifies the development of the proposed idea in to represent the structures and generate scenarios. In addition, according to Santos et al. (2015b) apud Oksanen (2007), a computational model of planning and management of agricultural machinery is developed with the aim of providing acceptable solutions to solve problems. In this context, Hansen et al. (2007) created a model with the aim of determining a standard route for bedside maneuvers in order to obtain the shortest total waiting time to perform them. Santos et al. (2014a) used the computational model "ColheCana" in order to assess field efficiency and cost of the sugarcane mechanized harvesting system.

Mercante et al. (2010) elaborated the "software PRAPRAG" in a programming language to observe the cost of self-propelled sprayers. Buckmaster (2003) developed the model "TRACTOR COST" to determine the fuel costs by means of specific consumption of the agricultural tractor. Khoub Bakht et al. (2009), Rashidi and 
Ranjbar (2010), and Niari et al. (2012) developed models to analyze the participation of spare parts, salary of operator and mechanic, lubricants, oil filter, and fuel in the cost of repair and maintenance of agricultural tractors. Rohani et al. (2011) elaborated a model in order to solve problems in the cost with repair and maintenance of tractors.

Considering the importance of the length of crop rows in the operational and economic performance of mechanized spraying systems, the aim of this study was to assess the impact caused by it on the operational cost of the hydraulic sprayer for sugarcane management practices.

\section{MATERIAL AND METHODS}

In this study, a model scenario was considered for a mill called Fictitious Mill, with its own area of 22,000 ha. Hydraulic self-propelled, trailed, and aerial sprayers were considered in the control product application system that serves the sugarcane cultivation of this mill. The equipment and economic, technical, and operational characteristics are shown in Table 1.

Table 1. Economic, technical, and operational variables of the equipment.

\begin{tabular}{lcccccc}
\hline \multicolumn{1}{c}{ Variable } & Abbreviation & Unit & $\begin{array}{c}\text { Self- } \\
\text { propelled } \\
\text { sprayer }\end{array}$ & Tractor & Sprayer & Airplane \\
\hline Initial Value & IV & US\$ & 170,350 & 38,005 & 37,736 & 233,154 \\
Rated Power & Power & $\mathrm{kW} / \mathrm{CV}$ & $147 / 200$ & $74 / 100$ & - & $238 / 324$ \\
Number of Spray Tips & NST & Number & 56 & - & 49 & 42 \\
Spacing between Tips & ST & $\mathrm{cm}$ & 50 & - & 50 & 35.71 \\
Total Tank Volume & TTV & $\mathrm{L}$ & 3,000 & - & 3,000 & 950 \\
Operating Speed & OS & $\mathrm{km} \mathrm{h}^{-1}$ & 9.0 & & 9.0 & 222.0 \\
Bedside Maneuver Speed & $\mathrm{BMS}$ & $\mathrm{km} \mathrm{h}^{-1}$ & 5.0 & & 5.0 & - \\
Refueling Speed & $\mathrm{RS}$ & $\mathrm{km} \mathrm{h}^{-1}$ & 20.0 & & 20.0 & - \\
Transfer Speed from the Flight Track to the & TSFTF & $\mathrm{km} \mathrm{h}^{-1}$ & - & & - & 280.0 \\
Field & & & & &
\end{tabular}

To meet the objective, a computational model named TratoCana Version 2.0, which meets the basic characteristics of mechanized spraying for sugarcane cultivation, was developed. This model is based on a flowchart (Figure 1) constructed according to the symbology proposed by Oakland (2007).

TratoCana Version 2.0 was developed in an Excel $^{\circledR}$ spreadsheet and in Visual Basic ${ }^{\circledR}$ programming language. The model begins its operation $(1)^{2}$ with the input of data from the crop (2), such as the area to be sprayed. Item (3) is the climate data input: total number of days to perform spraying, working day, relative air humidity, air temperature, and wind speed. Crop and climate data result in operational rhythm (4).

${ }^{2}$ Numbers in parentheses refer to the flowchart of Figure 1.

Data input (5) refers to technical/operational characteristics of terrestrial spraying: number of tips, spacing between tips, tip flow rate, refueling time, average distance between field and refueling pump, average length of cultivation stripes, operating speed, bedside maneuver speed, refueling speed, total volume of the sprayer tank, field efficiency, and others. Data input (6) refers to technical/operational characteristics of aerial spraying: number of tips, spacing between tips, tip flow rate, refueling time, average distance between field and refueling pump, average distance between flight track and field, average length of cultivation stripes, operating speed, transfer speed from the flight track to the field, effective strip width, time of each return curve, time in the ground between each flight, aerial application rate, total volume of the sprayer tank, field efficiency, and others.

The operational rhythm, associated with technical/operational characteristics of spraying, determines the operational performance of sprayer ${ }^{3}$, tractor plus sprayer, and airplane (7): available time, operational field capacity, application volume, total application flow rate, total time of displacement and refueling, total traveled distance, machine-hours, and number of equipment required.

${ }^{3}$ When the text refers only to sprayer it is because it is selfpropelled type equipment.

The results of operational performance, associated with the data of economic performance of machines (8): initial and final value, useful life in 
years and hours, interest per year, housing, insurance and fees, fuel consumption, repair and maintenance factor, and others make it possible to calculate the economic performance (9), which refers to the cost per hour, area, and liter.

The results of the model (10) allow the user to assess the operational and economic performance of the mechanized spraying and decide (11) on viability (12) or not. In case the spraying is not feasible for the user (13) or the user choose to assess another scenario, new data should be inserted.

The numbers in parentheses refer to the flowchart of Figure 1.

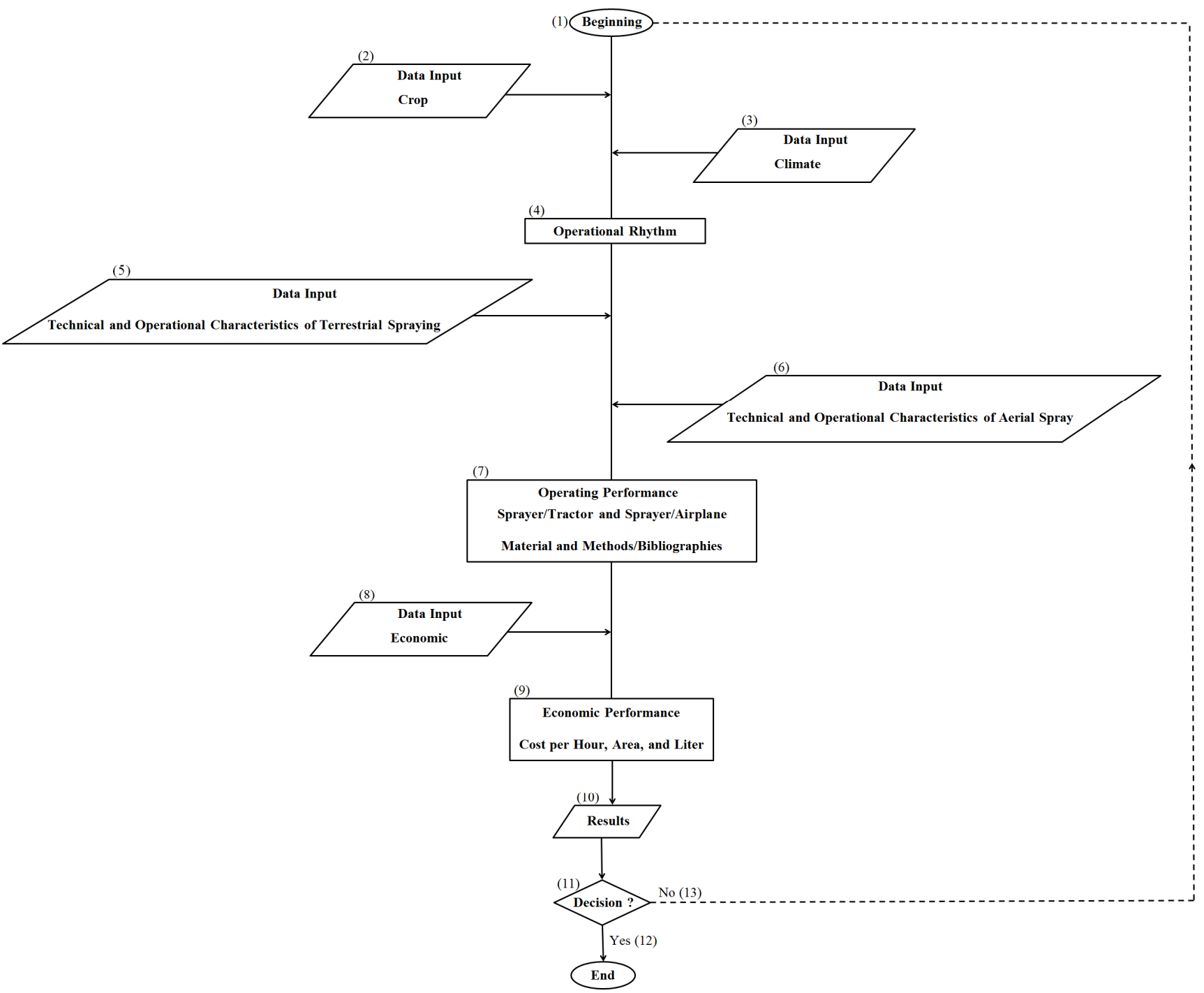

Figure 1. General flow chart of the computational model.

\section{Agroclimatic factors}

The factor climate of the mill was defined by the number of working days unsuitable for spraying (NWDUS) according to the methodological proposal of Santos (2017). The proposal considers agroclimatic parameters such as relative air humidity (RAH), wind speed (WS), and air temperature (AT).

Mean values of agroclimatic parameters of the mill were considered in order to meet this proposal (Table 2). These data refer to Rio Largo, AL, for the year of 2014, and were gathered from the Agrometeorological Station of the Center of Agrarian Sciences of the Federal University of Alagoas (CECA/UFAL).

The number of working days unsuitable for spraying (NWDUS) was considered in the available time (AT), according to the methodology of Mialhe (1974). The calculation of the available time (AT) was obtained by summing the number of Sundays and holidays (NSH) and number of working days unsuitable for spraying (NWDUS) then subtracting the total number of days (TN) and the values associated to the working hours (WH). 
Table 2. Mean values of agroclimatic parameters.

\begin{tabular}{|c|c|c|c|c|c|c|c|c|c|c|c|c|c|c|}
\hline \multirow{2}{*}{ Parameter } & \multirow{2}{*}{ Abbreviation } & \multirow{2}{*}{ Unit } & \multicolumn{12}{|c|}{ Months of Control Product Application } \\
\hline & & & Jan. & Feb. & Mar. & Apr. & May & June & July & Aug. & Sept. & Oct. & Nov. & Dec. \\
\hline Air Temperature & AT & ${ }^{\circ} \mathrm{C}$ & 26.15 & 26.05 & 26.75 & 27.70 & 25.70 & 24.50 & 23.95 & 23.35 & 24.65 & 24.65 & 26.25 & 25.60 \\
\hline $\begin{array}{c}\text { Relative Air } \\
\text { Humidity }\end{array}$ & RAH & $\%$ & 65.65 & 67.60 & 67.40 & 68.91 & 71.75 & 69.20 & 67.35 & 69.95 & 70.60 & 69.05 & 63.95 & 66.10 \\
\hline Wind Speed & WS & $\begin{array}{l}\mathrm{Km} \\
\mathrm{h}^{-1}\end{array}$ & 7.20 & 6.12 & 6.12 & 5.40 & 5.40 & 6.12 & 6.12 & 6.12 & 6.48 & 6.84 & 6.84 & 6.84 \\
\hline
\end{tabular}

Source: CECA/UFAL

\section{Operational performance}

The operational performance of the set sprayer plus tractor and sprayer was based on the proposals of Mialhe (1974) and Santos et al. (2014b). These proposals define the number of equipment necessary to carry out control product application in the sugarcane cultivation of the mill.

The number of machines (NM) was calculated by the ratio between the operational rhythm (OR) and operational field capacity (OFC) of the equipment.

The operational rhythm (OR) was calculated by the ratio between the area to be sprayed (AS) and the available time to perform the agricultural operation (AT).

The operational field capacity (OFC) was calculated by the association between the total boom width (TBW), operating speed (OS), and field efficiency (FE).

The spray solution volume to be applied is in accordance with the proposals of Gadanha Júnior (2000) and Matuo et al. (2010). Application volume (AV) was calculated by the ratio between tip flow rate (TF), spacing between tips (ST) and operating speed (OS).

The total application rate (TAR) was defined by the association between the application volume (AV) and operational field capacity (OFC).

The travel time for refueling (TTR) is the round trip time to the field. The travel time was calculated by the ratio between the average distance between field and refueling pump (ADFRP) and refueling speed (RS).

The total travel and refueling time (TTRT) refers to the time spent to travel to the control product tank, refueling in the tank, and the return travel to the field. The total time was calculated by the sum of the travel time for refueling (TTR) and refueling time (RT).

The number of refueling (NR) was defined by the ratio of the application volume (AV), area to be sprayed (AS), and total tank volume (TTV) of the equipment.

The bedside maneuver distance (MD) was determined by the maneuver turning radius (MTR).

The bedside maneuver time (MT) was calculated by the ratio between the maneuver distance (MD) and maneuver speed (MS).

The number of bedside maneuvers (NBM) was defined by the ratio between the area to be sprayed (AS), total boom width (TBW), and average length of cultivation stripes (ALCS).

The operational performance of the airplane was also calculated according to the proposal of Mialhe (1974) and Santos et al. (2014b) to define the number of equipment required, as described for the sprayer and set tractor plus sprayer.

The operational field capacity (OFC) of the airplane is in accordance with the adjusted proposal of Araújo (2009). It is calculated by the association of total volume of the sprayer tank (TVST), application volume (AV), distance from the flight track to the field (DFTF), travel speed from the flight track to the field (TSFTF), effective strip width (ESW), time of each return curve (TRC), average length of crop rows (ALCR), and time in the ground between each flight (TGF).

\section{Economic performance of the sprayer}

The total cost of the sprayer (TCS) was determined by the association between the operational cost of the sprayer (OCS) and the area to be sprayed (AS).

The operational cost of the sprayer (OCS) was defined as the ratio between the hourly cost of the sprayer (HCS) and the operational field capacity (OFC).

The operational application cost of the sprayer (OACS) was determined by the ratio between the hourly cost of the sprayer (HCS) and the total application rate (TAR).

The hourly cost of the sprayer (HCS) was calculated by the sum of the hourly fixed cost of the sprayer (HFCS) and the variable cost of the sprayer (VCS).

The hourly fixed cost of the sprayer (HFCS) was calculated according to the methodology proposed by ASABE (2011), being defined by the 
ratio between annual fixed cost (AFC) and the number of hours worked per year (NHWY).

The variable cost of the sprayer (VCS) was defined by the sum of the cost with fuel (CF) and the cost with repair and maintenance (CRM).

The calculation of sprayer fuel consumption was adapted from Banchi et al. (2008). The adaptation occurred by the adoption of average consumption values per motor power range of agricultural tractors.

The calculation of the cost with repair and maintenance (CRM) and factor of repair and maintenance (FRM) of the sprayer are in accordance with ASABE (2011).

\section{Economic performance of the set tractor plus sprayer}

The total (TCS), operational (OCS), operational application (OACS), and hourly (HCS) cost of the set ${ }^{4}$ were calculated in the same way as that of the sprayer.

The hourly fixed cost of the set (HFCS) was calculated according to the methodology proposed by ASABE (2011), as the calculation of the hourly fixed cost of the sprayer.

The variable cost of the set (VCS) was determined by the sum of the cost with the tractor fuel (CTF) and with repair and machine maintenance (CRM).

The calculation of the tractor fuel consumption considered the average values of consumption by motor power range of agricultural tractors proposed by Banchi et al. (2008).

The calculation of the cost with repair and maintenance (CRM) and factor of repair and maintenance (FRM) of the set are in accordance with ASABE (2011).

\section{Economic performance of the airplane}

The total (TCA), operational (OCA), operational application (OACA), and hourly (HCA) cost of the airplane were calculated in the same way as for the sprayer and set.

The hourly fixed cost of the airplane (HFCA) was calculated according to the methodology proposed by ASABE (2011), as the calculation of the hourly fixed cost of the sprayer and set.

The variable cost of the airplane (VCA) was determined by the sum of the cost with the airplane fuel (CAF) and with repair and maintenance (CRM).

For the airplane fuel consumption, an

\footnotetext{
${ }^{4}$ When only the word "set" is mentioned, it is a tractor and sprayer (trailed or mounted).
}

average value was considered according to the best power to be used and a higher working regime, according to EMBRAER/NEIVA (2012).

The calculation of the cost with repair and maintenance (CRM) of the airplane is in accordance with ASABE (2011). The factor of repair and maintenance (FRM) is in accordance with the data provided by PBA AVIATION (2012).

\section{Validation}

TratoCana Version 2.0 was validated by comparing simulation results with raw (primary) data obtained in the field and data from the bibliography (secondary). The sensitivity and consistency analysis of the computational model was performed by the cost.

\section{RESULTS AND DISCUSSION}

The average values of agroclimatic parameters of the mill, which is related to the agroclimatic conditions of Rio Largo, AL, in 2014, resulted in a number of working days unsuitable for spraying (NWDUS) of 257 days and available time (AT) of 2,583 hours.

Figure 2 shows the data and input variables of the computational model in the spreadsheet.

Figure 3 shows the data and output variables of the computational model in the spreadsheet.

Figure 4 shows the data and input variables of the computational model in programming language.

Figure 5 shows the data and output variables of the computational model in programming language. 


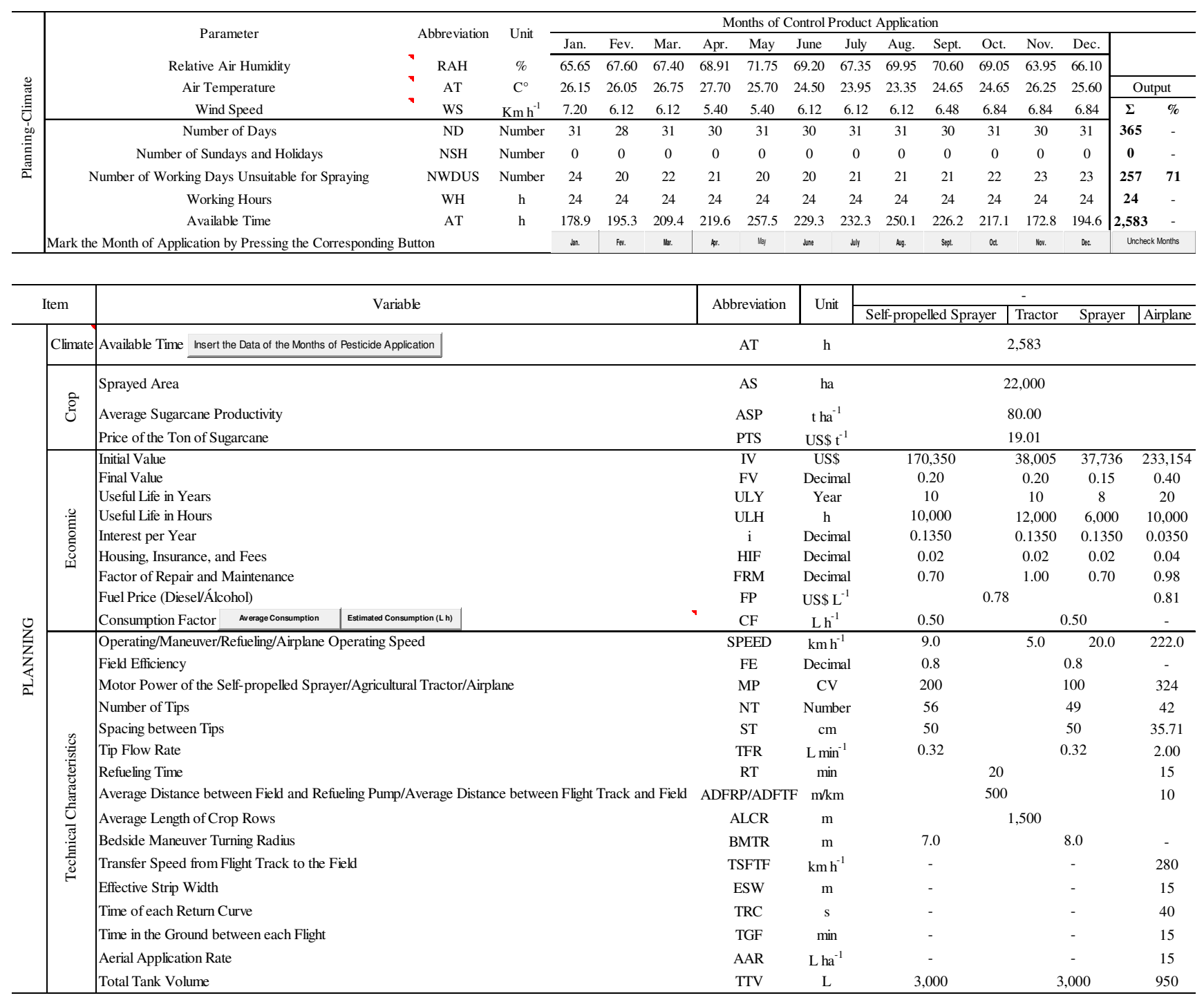

Figure 2. Data and input variables of the computational model in spreadsheet. 


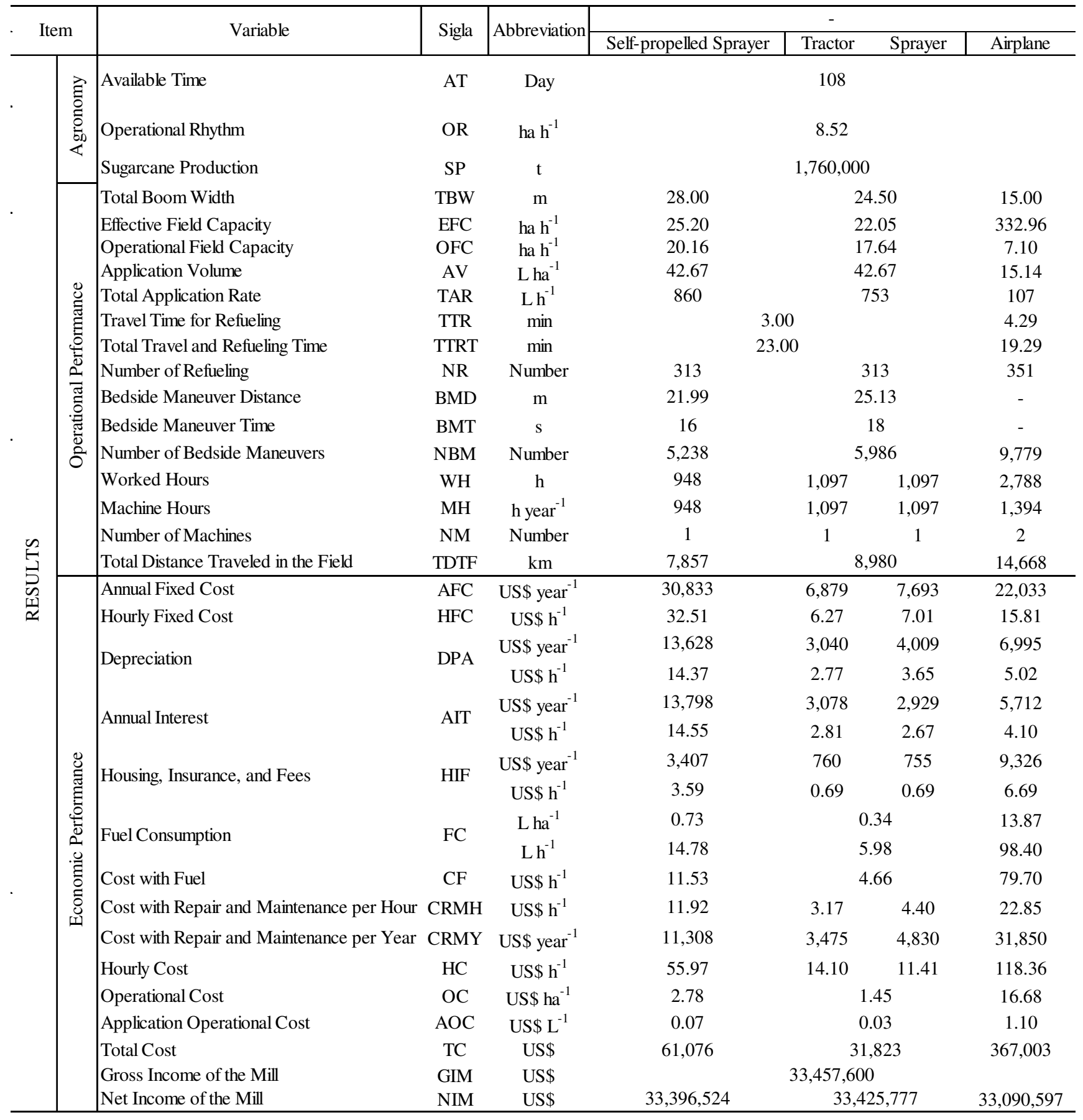

Figure 3. Data and output variables of the computational model in spreadsheet. 
Simulation of the length...

SANTOS, N. B. dos

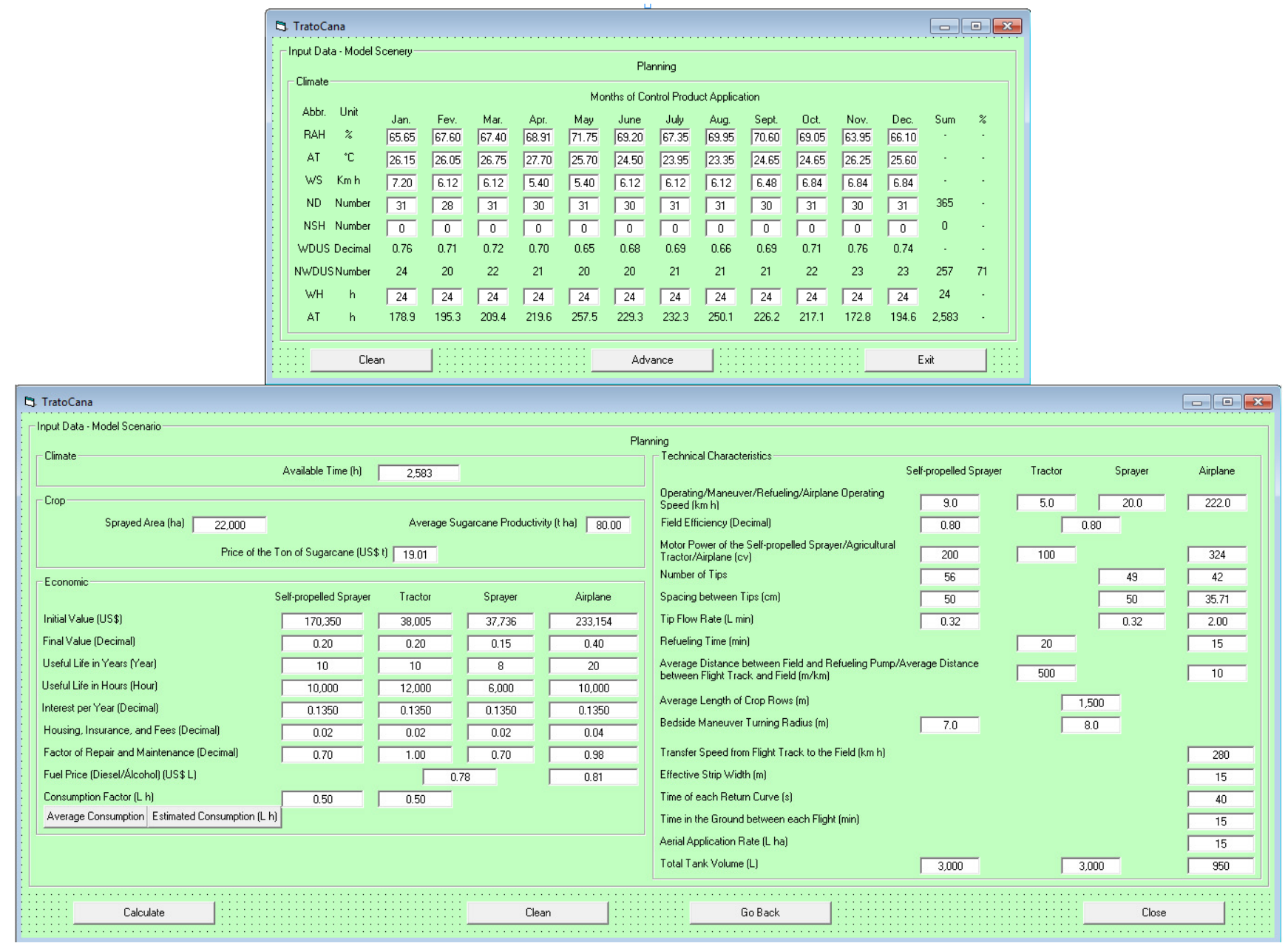

Figure 4. Data and input variables of the computational model in programming language.

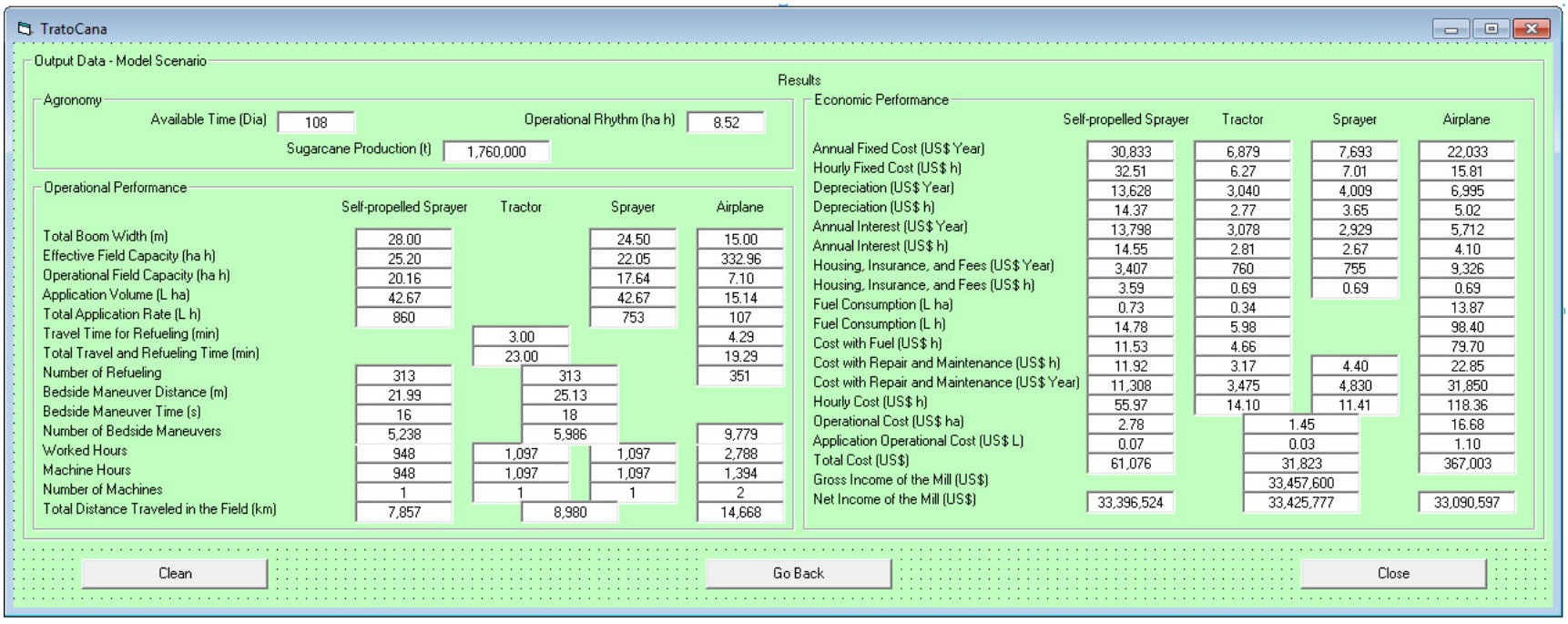

Figure 5. Data and output variables of the computational model in programming language. 
According to the results of a model the operational cost of the sprayer (Figure 6). scenario, the average length of crop rows influenced

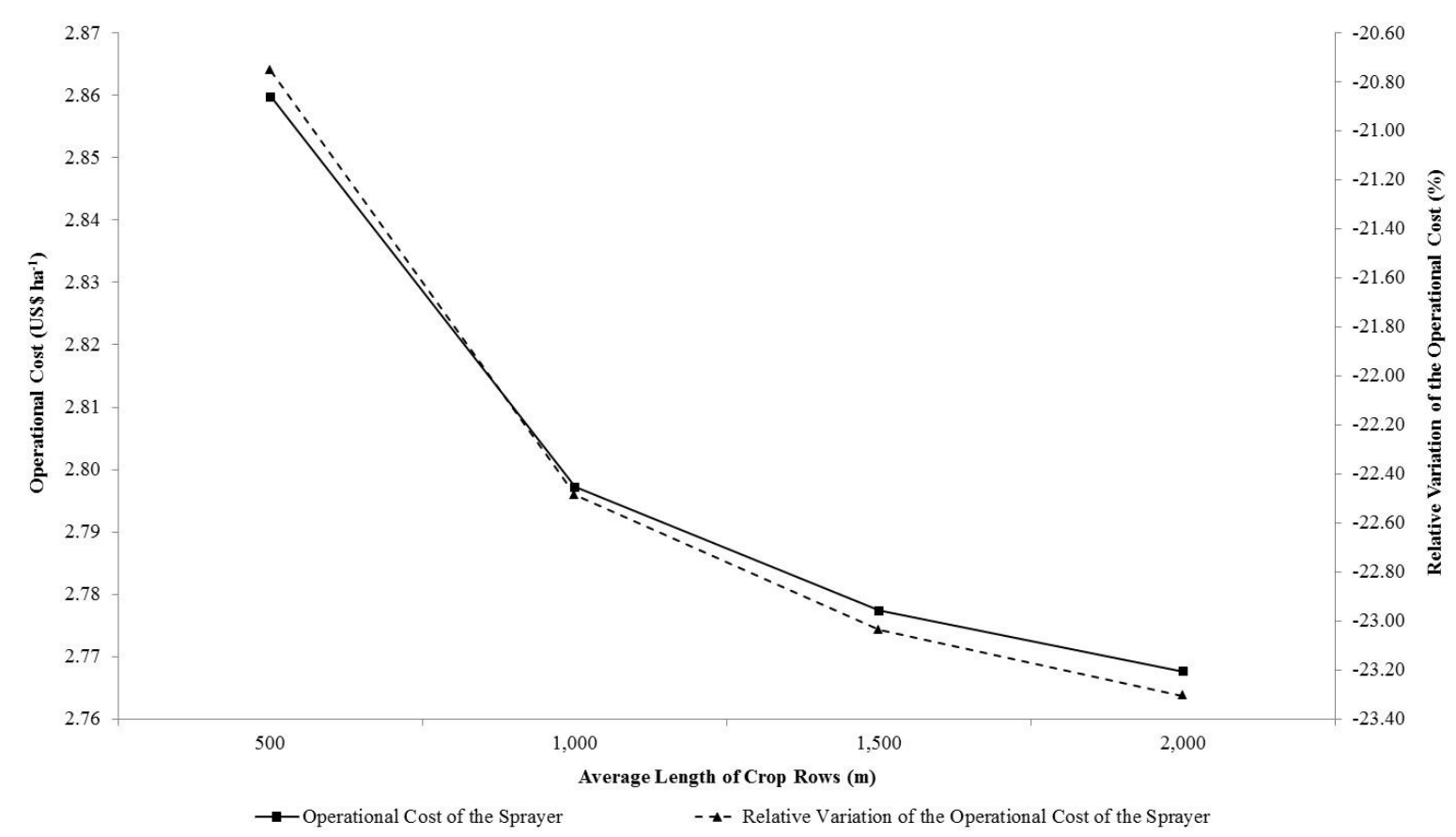

Figure 6. Operational cost of the sprayer and relative variation of the operational cost as a function of the average length of crop rows.

Having as reference a length of $100 \mathrm{~m}$, the variation in the operational cost in $500 \mathrm{~m}$ had a reduction of $-20.75 \%$ and 15,714 bedside maneuvers, while in $1,000 \mathrm{~m}$, it was of $-22.49 \%$ and 7,857 maneuvers. For a length of $1,500 \mathrm{~m}$, the variation in cost was $-23.04 \%$, with 5,238 maneuvers, while in $2,000 \mathrm{~m}$, it was reduced in $-23.31 \%$, being necessary to perform 3,929 maneuvers.

The average length of crop rows has a share in the operational cost of the set (Figure 7).

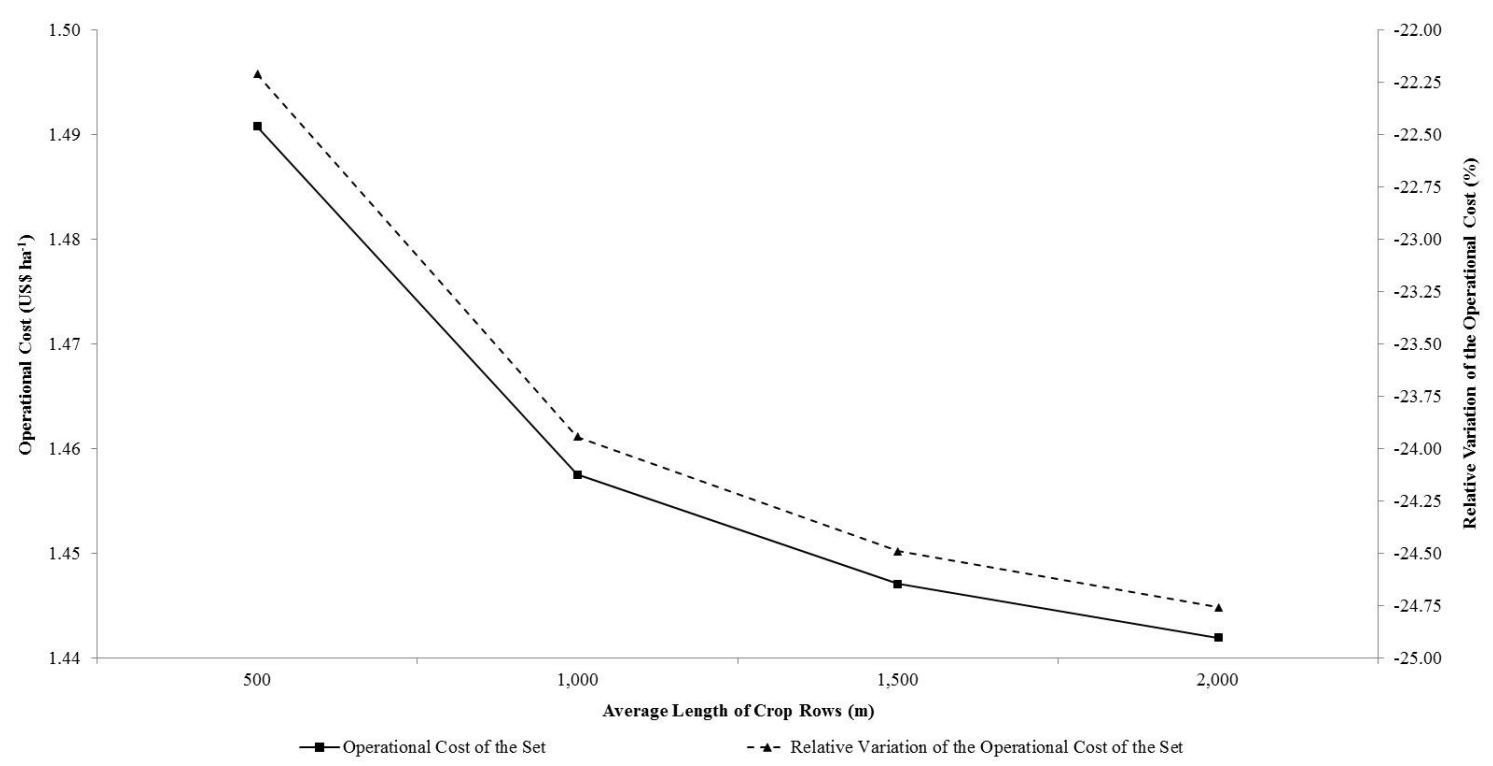

Figure 7. Operational cost of the set and relative variation of the operational cost as a function of the average length of crop rows.

Having as reference a length of $100 \mathrm{~m}$, the variation in the operational cost in $500 \mathrm{~m}$ had a 
reduction of $-22.21 \%$, requiring 17,959 bedside maneuvers, while in $1,000 \mathrm{~m}$, this variation was $-23.94 \%$, with 8,980 maneuvers. For a length of $1,500 \mathrm{~m}$, the variation in cost resulted in a reduction of $-24.49 \%$, with 5,986 maneuvers, while for 2,000 $\mathrm{m}$, the variation was reduced by $-24.76 \%$, being required 4,490 maneuvers.

The average length of crop rows interferes with the operational cost of the airplane (Figure 8).

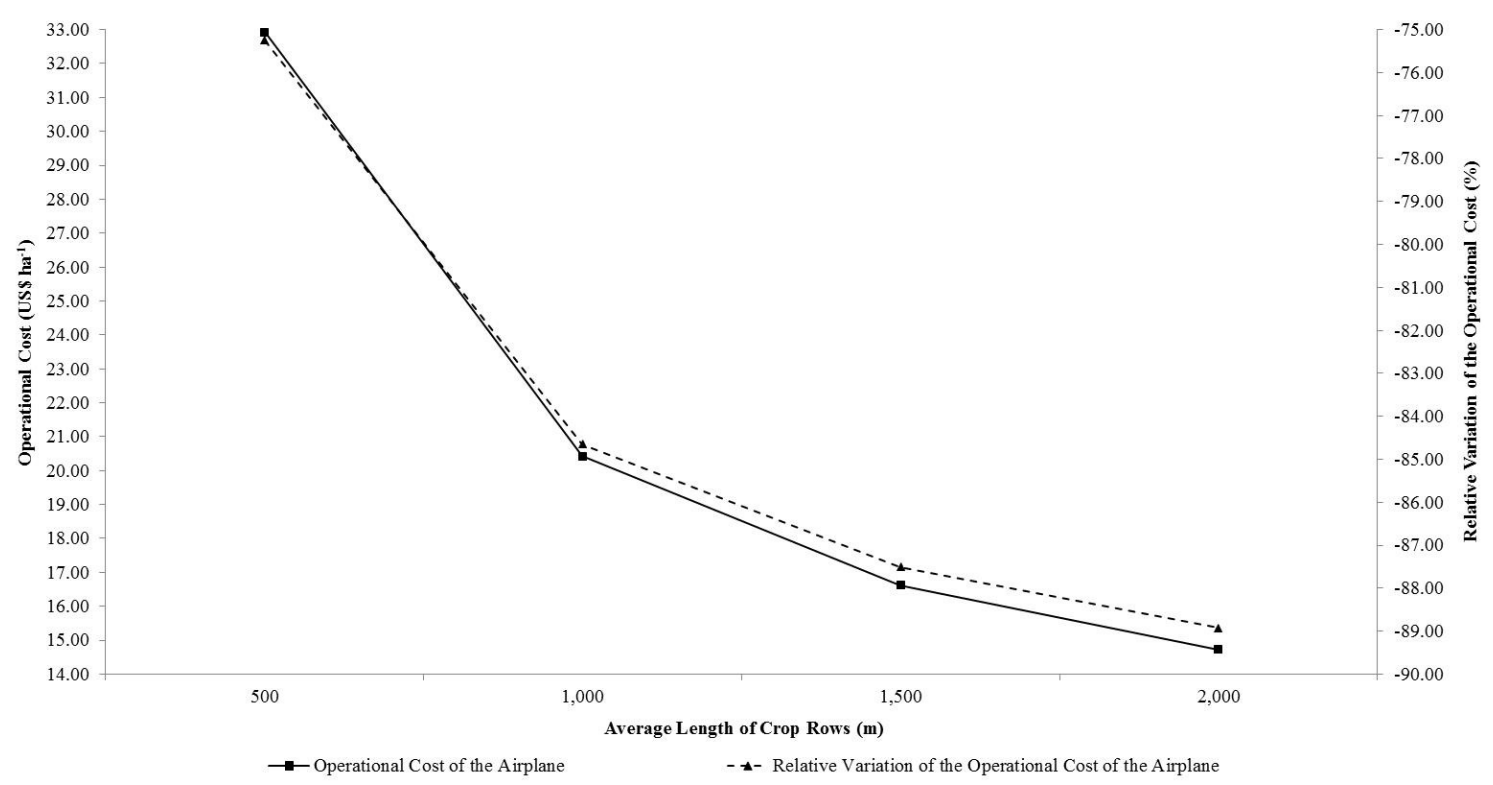

Figure 8. Operational cost of the airplane and relative variation of the operational cost as a function of the average length of crop rows.

Having as reference a length of $100 \mathrm{~m}$, the change in the operational cost in $500 \mathrm{~m}$ was reduced by $-75.25 \%$, with 29,337 bedside maneuvers, while in $1,000 \mathrm{~m}$, this variation was reduced by $-84.65 \%$, being required 14,668 maneuvers. For a length of $1,500 \mathrm{~m}$, the variation in cost resulted in a reduction of $-87.50 \%$, with 9,779 maneuvers to be performed, while in $2,000 \mathrm{~m}$, this variation was reduced by $-88.93 \%$, with 7,334 maneuvers.

According to the model scenario (Figures 6, 7 , and 8), an average length of crop rows of 1,000 , 1,500 , and $2,000 \mathrm{~m}$ resulted in a reduction in the number of bedside maneuvers by $50.00,66.67$, and $75.00 \%$, respectively. The increase in the average length of crop rows results in a polynomial reduction of the operational cost. However, this increase in length has a strong positive impact (variation) on the operational cost. According to Santos et al. (2015a), this is due to an increase in the productive time, worked time, and worked hours of machines. Therefore, according to Santos and Gadanha Júnior (2016), plots should be systematized with a rectangular geometric shape or a winding strip to obtain a long length of crop rows and reduce the number of maneuvers.

\section{CONCLUSIONS}

An increased length of crop rows is advantageous because it reduces bedside maneuvers and the operational cost of the machine.

The mills must carry out the systematization of their areas to enable mechanized operations.

RESUMO: O Brasil é o maior produtor mundial de cana-de-açúcar destinada às usinas e tem produtividade média, superior aos demais países produtores dessa matéria-prima. A aplicação de defensivos agrícolas em canaviais das agroindústrias é realizada em extensas áreas de cultivo, com pulverizadores hidráulicos autopropelidos, tratorizados e aéreo. Para tanto é necessário sistematizar as áreas de cultivo, tornando os talhões com longo comprimento de fileiras de cultivo, a fim de diminuir as manobras de cabeceira das máquinas. O objetivo do trabalho é avaliar o impacto causado pelo comprimento das fileiras de cultivo no custo operacional de pulverizadores hidráulicos para os tratos culturais de cana-de-açúcar. Pela dificuldade que existe em realizar o trabalho e atender o objetivo nas condições de campo, optou-se em desenvolver um modelo computacional denominado TratoCana, em planilha eletrônica e em linguagem de programação. O modelo foi 
verificado quanto a possíveis erros de rotina, validado, utilizado na análise dos fatores e na geração de cenários. Os resultados evidenciaram que o comprimento das fileiras de cultivo, impacta positivamente no desempenho operacional e econômico dos equipamentos.

PALAVRAS-CHAVE: Mecanização agrícola. Pulverizadores hidráulicos. Planejamento e gerenciamento. Manobra de cabeceira. Modelo computacional. Custo.

\section{REFERENCES}

AMERICAN SOCIETY OF AGRICULTURAL AND BIOLOGICAL ENGINEERS - ASABE. Agricultural machinery management data ASAE D497.7. In: ASABE Standards. St. Joseph, 2011. 8 p.

ARAÚJO, E. C. Aviação agrícola: voando alto. Cultivar Máquinas, Pelotas, n. 82, p. 20-24, 2009.

BALASTREIRE, L. A. Máquinas agrícolas. São Paulo: Manole. 1990. 307 p.

BANCHI, A. D.; LOPES, J. R.; ZAGO, C. A. Uso anual e consumo de combustível em frotas agrícolas.

Revista Agrimotor, São Paulo, n. 39, p. 8-10, 2008.

BUCKMASTER, D. R. Benchmarking tractor costs. Applied Engineering in Agriculture, St. Joseph, v. 19, n. 2, p. 151-154, 2003.

COMPANHIA NACIONAL DE ABASTECIMENTO - CONAB. Acompanhamento da safra brasileira de cana-de-açúcar, terceiro levantamento. Brasília, v. 4, n. 3, 2017. Disponível em:

<https://www.conab.gov.br/index.php/component/k2/item/download/16105_76d98d8ca57>. 23 Abr. 2018.

EMPRESA BRASILEIRA DE AERONÁUTICA - EMBRAER/NEIVA. Especificações: características principais ipanemão 100\% etanol. Botucatu, 2012. Disponível em:

<http://www.embraeragricola.com.br/Documents/Spec_FINAL\%20APROVADO.pdf>. 30 Nov. 2016.

GADANHA JÚNIOR, C. D. Avaliação do tempo de resposta de controladores eletrônicos em pulverizadores agrícolas. 2000. $125 \mathrm{f}$. Tese (Doutorado em Energia na Agricultura) - Faculdade de Ciências Agronômicas, Universidade Estadual Paulista "Júlio de Mesquita Filho", Botucatu, 2000.

HANSEN, A. C.; ZHANG, Q.; WILCOX, T. A. Modeling and analysis of row harvest harvesting patterns by combines. Transactions of the ASABE, St. Joseph, v. 50, n. 1, p. 5-12, 2007.

HUNT, D. Farm power and machinery management. Ames: Iowa State University Press, 1995. 363 p.

KHOUB BAKHT, G. M.; AHMADI, H.; AKRAM, A.; KARIMI, M. Repair and maintenance cost models for mf 285 tractor: a case study in central region of Iran. Advances in Biological Research, Dubai, v. 3, n. 1-2, p. 19-23, 2009.

MATUO, T.; PIO, L. C.; RAMOS, H. H..; FERREIRA, L. R. Proteção de plantas: tecnologia de aplicação dos agroquímicos e equipamentos. Viçosa: UFV, 2010. 73 p.

MERCANTE, E.; SOUZA, E. G.; JOHANN, J. A.; GABRIEL FILHO, A.; URIBE-OPAZO, M. A. Praprag software para planejamento racional de máquinas agrícolas. Engenharia Agrícola, Jaboticabal, v. 30, n. 2, p. 322-333, 2010.

MIALHE, L. G. Manual de mecanização agrícola. São Paulo: Agronômica Ceres, 1974. 301 p.

NIARI, S. M.; RANJBAR, I.; RASHIDI, M. Prediction of repair and maintenance costs of john deere 4955 tractors in Ardabil Province, Iran. World Applied Sciences Journal, Dubai, v. 19, n. 10, p. 1412-1416, 2012. 
OAKLAND, J. Gerenciamento da qualidade total tqm. São Paulo: Nobel, 2007. 459 p.

OKSANEN, T. Path planning algorithms for agricultural field machines. 2007. 110 p. Dissertation (Doctorate of Science in Technology) - Helsinki University of Technology, Espoo, 2007.

PBA AVIATION. Conheça o ipanema. Cachoeira do Sul, 2012. Disponível em: $<\mathrm{http} / / / \mathrm{www}$.pbaaviation.com.br/index.php?option=com_content\&view=article\&id=58\&Itemid=58\&showall= 1>. 03 Fev. 2014.

RASHIDI, M.; RANJBAR, I. Modeling of repair and maintenance costs of john deere 4955 tractors in Iran. American-Eurasian Journal of Agricultural \& Environmental Sciences, Dubai, v. 9, n. 6, p. 605-609, 2010.

ROHANI, A.; ABBASPOUR-FARD, M. H.; ABDOLAHPOUR, S. Prediction of tractor repair and maintenance costs using Artificial Neural Network. Expert Systems with Applications, Amsterdam, v. 38, n. 7, p. 8999-9007, 2011.

SANTOS, N. B. dos. Method to determine unsuitable days for agricultural spraying. Nucleus, Ituverava, v. 14, n. 1, p. 141-144, 2017.

SANTOS, N. B. dos; CAVALCANTE, D. S.; FERNANDES, H. C.; GADANHA JÚNIOR, C. D. Tempo é dinheiro. Cultivar Máquinas, Pelotas, n. 149, p. 36-38, 2015 a.

SANTOS, N. B. dos; FERNANDES, H. C.; GADANHA JÚNIOR, C. D. Economic impact of sugarcane (Saccharum spp.) loss in mechanical harvesting. Científica, Jaboticabal, v. 43, n. 1, p. 16-21, 2015b.

SANTOS, N. B. dos; GADANHA JÚNIOR, C. D. Colheita reformulada. Cultivar Máquinas, Pelotas, n. 159, p. 08-09, 2016.

SANTOS, N. B. dos; SILVA, R. P.; GADANHA JUNIOR, C. D. Economic analysis for sizing of sugarcane (Saccharum spp.) mechanized harvesting. Engenharia Agrícola, Jaboticabal, v. 34, n. 5, p. 945-954, 2014 b.

SANTOS, N. B.; CAVALCANTE, D. S.; FERNANDES, H. C.; GADANHA JÚNIOR, C. D. Simulação da eficiência de campo da colheita mecanizada de cana-de-açúcar (Saccharum spp.). Revista Energia na Agricultura, Botucatu, v. 29, n. 1, p. 09-13, 2014a.

WILLIAMS, H. P. Model building in mathematical programming. 4. ed. Chichester: John Wiley, 2008. 354 p. 